\title{
Organisert mammografiscreening - flere fordeler enn ulemper
}

\author{
Ferske europeiske samleanalyser indikerer at mammografiscreening reduserer brystkreftdødeligheten, \\ men innebærer en viss risiko for overdiagnostikk og falskt positive screeningresultater. I Norge mangler vi, \\ slik jeg ser det, sikre resultater hva gjelder mammografiscreening og brystkreftdødelighet. Norske tall for \\ overdiagnostikk varierer, mens risikoen for falskt positive prøveresultater synes å være på nivå med den \\ europeiske samleanalysen.
}

I september 2012 publiserte Journal of Medical Screening et supplement med åtte artikler fra europeiske screeningprogrammer med mammografi (1-8). Artiklene er samleanalyser utført av forskere fra ni land i Euroscreen Working Group. Effekt av screening på dødelighet av brystkreft, økt forekomst og falskt positive screeningresultater er hovedfokus i analysene. Jeg deltok $i$ arbeidsgruppen og gir i denne kommentaren en kort beskrivelse av hovedresultatene og diskuterer disse opp mot norske forhold.

\section{Dødelighet}

Formålet med mammografiscreening er å redusere brystkreftdødelighet. Etter randomiserte kontrollerte studier er kohortanalyser det mest stringente epidemiologiske studiedesignet. Ved insidensbaserte kohortanalyser kan man skille ut dødsfall blant kvinner som fikk diagnostisert brystkreft etter at de var invitert/møtt i programmet (2). Arbeidsgruppen vurderte slike studier som svært godt egnet til å evaluere effekten både for inviterte og deltakende kvinner i organiserte screeningprogrammer, forutsatt tilstrekkelig oppfølgingstid og justering for seleksjonsskjevhet. Samlestudien med kohortanalyser viste $25 \%(\mathrm{RR}=0,75 ; 95 \%$ KI 0,69-0,81) lavere brystkreftdødelighet blant inviterte versus ikke-inviterte og $38 \%$ $(\mathrm{RR}=0,62 ; 95 \% \mathrm{KI} 0,56-0,69)$ lavere brystkreftdødelighet blant møtte versus ikkemøtte.

Pasient-kontroll-studier ble også vurdert som egnet, forutsatt tilstrekkelig justering for seleksjonsskjevhet (3). Ved analyse av studier med slikt design var brystkreftdødelighet henholdsvis $31 \%(\mathrm{RR}=0,69 ; 95 \%$ KI 0,57-0,83) lavere for inviterte versus ikke-inviterte og $48 \%(\mathrm{RR}=0,52 ; 95 \% \mathrm{KI}$ $0,42-0,65)$ lavere for møtte versus ikkemøtte (3).

Trendstudier vil ikke kunne ta hensyn til om kvinnene fikk diagnostisert sykdommen før eller etter at hun var invitert/møtt til screeningprogrammet. Resultater fra slike studier bør derfor, ifølge arbeidsgruppen, i all hovedsak ikke tas hensyn til (1).

\section{Overdiagnostikk}

Overdiagnostikk er definert som brystkreft som ikke ville blitt diagnostisert i kvinnens levetid dersom hun ikke var invitert/møtt til screening. Dette er et teoretisk begrep, og estimatene er basert på matematiske beregninger med en rekke forutsetninger. Det er $i$ dag ingen enighet om hvilken metode som er best eller hvilke forutsetninger som må ligge i beregningene $(4,9)$. Tilstrekkelig oppfølgingstid etter at kvinnene ikke lenger blir inviterte til screening samt justering for naturlig økning i forekomst og forskyvning i diagnosetidspunktet (lead-time) blir fremstilt som avgjørende for å kunne anslå

\section{«Videre beregnet man at 30 kvinner ville dø av brystkreft uten screening, mot 21-23
med screening»}

estimatet så presist som mulig. Definerer man overdiagnostikk som en prosentvis andel av den forventede forekomsten i fravær av screening, er justerte estimater i samlestudien 1-10\% (gjennomsnittlig $6,5 \%$ ) for kvinner som ble screenet fra de var 50 år til de var 69 år og fulgt ti år etter siste invitasjon (4).

\section{Falskt positive screeningresultater} En positiv screeningtest som resulterer i et negativt resultat etter supplerende undersøkelser kalles et falskt positivt screeningresultat. Kvinner som kalles inn til tilleggsundersøkelser etter en screeningtest kan oppleve forbigående uro og engstelse (10, 11). Samleanalyser viste at risikoen for å bli innkalt til tilleggsundersøkelser med røntgenbilder og/eller ultralyd med negativt resultat i løpet av ti screeningtester over 20 år var $17 \%$. Den kumulative risikoen for å gjennomgå tilleggsbilder og/eller ultralyd og en påfølgende nåleprøve med benignt resultat var $3 \%$ (5).

\section{Fordeler mot ulemper}

Arbeidsgruppen beregnet at dersom 1000 kvinner i alderen 50-69 år screenes hvert annet år og deretter følges i ti år, til de er 79 år, vil man forvente å diagnostisere 71 brystkrefttilfeller, mot 67 tilfeller uten screening. Videre beregnet man at $30 \mathrm{kvinner}$ ville dø av brystkreft uten screening, mot 21-23 med screening. Av de 200 kvinnene med falskt positivt screeningresultat, ville 30 gjennomgå en nåleprøve med negativt resultat (8).

Et uavhengig, britisk panel har også evaluert ulike effekter av mammografiscreening. Deres resultater (9) ble publisert rett etter supplementet i Journal of Medical Screening. Mens Euroscreen working group baserte sine analyser på resultater fra organiserte screeningprogrammer (1-8), benyttet det britiske panelet resultater fra randomiserte studier (9). Konklusjonen var at brystkreftdødeligheten var $20 \%$ lavere blant inviterte enn blant ikke-inviterte. Overdiagnostikk ble beregnet til å være 11-20\%. Panelet vurderte gevinsten av mammografiscreening til å være større enn ulempene, og anbefaler videre mammografiscreening i Storbritannia. At de randomiserte studiene ble utført for 20-50 år siden og at de ikke var designet for å beregne omfanget av overskuddssvulster, ble beskrevet som svakheter. Videre beskrev de trendstudier som lite egnet til evaluering av mammografiscreening, mens kohort- og pasient-kontroll-studier som justerer for forskjeller mellom screenede og ikke-screenede, ble vurdert som akseptable. Panelet valgte allikevel ikke å beregne effekten av den type studier. De begrunnet det med at aktuelle justeringer muligens resulterer i estimater i favør av screening. Det synes derfor åpenbart at ingen studiedesign er feilfri, verken for beregning av dødelighet, den økte forekomsten eller falskt positive screeningresultater.

\section{Situasjonen i Norge}

Mammografiprogrammet startet i fire fylker i 1996 og ble landsdekkende i 2005 (12). Kvinner i alderen 50-69 år inviteres til mammografiscreening hvert annet år. Kreftregisteret er ansvarlig for administrasjon, kvalitetskontroll og evaluering av programmet.

Kreftstatistikken i Norge er i dag oppdatert til og med 2010. Det vil si at vi har begrenset oppfølgingstid, spesielt for kvinner bosatt i de fylkene som implemen- 
terte programmet sent. For å evaluere dødeligheten av brystkreft etter innføring av Mammografiprogrammet er det viktig å ha opplysninger på individnivå fra et tilstrekkelig antall inviterte kvinner som er invitert/har møtt i programmet mer enn én gang. Videre er det blitt hevdet at 10-15 års oppfølgingstid er nødvendig for å få så presise estimater som mulig (9). Så langt er det publisert to analyser på brystkreftdødelighet etter innføringen $(13,14)$. Ingen av analysene brukte individuelle opplysninger om når kvinnene var invitert eller møtt til screening, og oppfølgingstiden er ikke adekvat. Begge analysene viste om lag $10 \%$ lavere brystkreftdødelighet blant de antatt inviterte. Gitt manglene i studiene kan begge analysene ha undervurdert effekten av screeningprogrammet (15).

En annen utfordring i Norge er at det ikke finnes informasjon om bruk av mammografi utenfor programmet. Nye data viser at $32 \%$ av brystkreftsvulstene som ble diagnostisert blant kvinner som ikke møtte i programmet i Møre og Romsdal var asymptomatiske og derfor kan ha blitt diagnostisert ved screening ved private institutter (16). Dersom funnet er representativt for alle fylkene, er det mulig at dødelighetsreduksjonen underestimeres blant deltakerne og overestimeres blant de inviterte.

For å beregne omfanget av overdiagnostikk av brystkreftsvulster er en oppfølgingstid på ti år foreslått, men nylig publiserte studier antyder at 10-15 års - sågar livslang - oppfølging kan være nødvendig $(9,17)$. Det er publisert flere studier med tall fra Norge, med estimater på 10-67\% (17-20). Flere av studiene er blitt kritisert for metodiske svakheter $(21,22)$, og kun den med lavest estimat (17) bruker individdata for invitasjon og oppmøte. Sistnevnte studie viser $10-20 \%$ overskudd, avhengig av inklusjonskriterier.

Risikoen for falskt positivt screeningresultat i Mammografiprogrammet er tidligere beregnet til å være i samme størrelsesorden som samleanalysen, $17 \%$ for supplerende undersøkelser med tilleggsbilder og/ eller ultralyd og $3 \%$ for supplerende undersøkelser, inkludert en nåleprøve (23).

\section{Viktig dokumentasjon}

Den europeiske gruppen valgte å rette oppmerksomheten mot effekten av organiserte screeningprogrammer i Europa (1-8). Supplementet representerer derfor, slik jeg ser det, et viktig innlegg i debatten om nytte og kostnader av organisert mammografi- screening. Resultatene er noe mer i favør av screening enn hva det uavhengige evalueringspanelet fra England viste (9). Mens Euroscreen-gruppen konkluderer med at to kvinner reddes for hver overdiagnostiserte, konkluderte det uavhengige britiske panelet at tre kvinner ble diagnostisert for hver kvinne som ble reddet. Verken supplementet i Journal of Medical Screening (1-8) eller artikkelen i The Lancet (9) omtaler intervallkreft eller stadiespesifikk forekomst, hvilket er en svakhet.

Basert på resultater fra kvalitetsparametre har vi tidligere funnet at Mammografiprogrammet oppfyller internasjonale anbefalinger (12). Det er derfor å forvente at analyser basert på individdata og med adekvat oppfølgingstid vil vise en dødelighetsreduksjon som er i samsvar med samleanalysene i Journal of Medical Screening og resultater fra det engelske uavhengige evalueringspanelet. Resultater fra slike studier er forventet i løpet av 2013.

\section{Solveig Hofvind}

solveig.hofvind@kreftregisteret.no

Solveig Hofvind (f. 1961) er forsker ved forskningsavdelingen på Kreftregisteret og professor i radiografi ved Høgskolen i Oslo og Akershus, fakultet for helsefag. Hun var med i Euroscreen Working Group, som ledet arbeidet bak de åtte omtalte artiklene.

Forfatter har fylt ut ICMJE-skjemaet og oppgir ingen interessekonflikter.

\section{Litteratur}

1. Moss S, Nyström L, Jonsson $\mathrm{H}$ et al. The impact of mammographic screening on breast cancer mortality in Europe: a review of trend studies. J Med Screen 2012: 19 (suppl 1): 26-32.

2. Njor S, Nyström L, Moss S et al. Breast cancer mortality in mammographic screening in Europe: a review of incidence-based mortality studies. J Med Screen 2012; 19 (suppl 1): 33-41.

3. Broeders M, Moss S, Nyström L et al. The impact of mammographic screening on breast cancer mortality in Europe: a review of observational studies. J Med Screen 2012; 19 (suppl 1): 14-25.

4. Puliti D, Duffy S, Miccinesi $G$ et al. Overdiagnosis in mammographic screening for breast cancer in Europe: a literature review. J Med Screen 2012; 19 (suppl 1): 42-56.

5. Hofvind S, Ponti A, Patnick J et al. False-positive results in mammographic screening for breast cancer in Europe: a literature review and survey of service screening programmes. J Med Screen 2012; 19 (suppl 1): 57-66.

6. Giordano L, von Karsa L. Tomatis M et al. Mammographic screening programmes in Europe: organization, coverage and participation. J Med Screen 2012; 19 (suppl 1): $72-82$.

7. Giordano L, Cogo C, Patnick J et al. Communica- ting the balance sheet in breast cancer screening J Med Screen 2012; 19 (suppl 1): 67-71.

8. Paci E, EUROSCREEN Working Group. Summary of the evidence of breast cancer service screening outcomes in Europe and first estimate of the benefit and harm balance sheet. J Med Screen 2012; 19 (suppl 1): 5-13

9. Independent UK Panel on Breast Cancer Screening. The benefits and harms of breast cancer screening: an independent review. Lancet 2012 380: 1778-86.

10. Brewer NT, Salz T, Lillie SE. Systematic review: the long-term effects of false-positive mammograms. Ann Intern Med 2007; 146: 502-10.

11. Schou Bredal I, Kåresen R, Skaane P et al. Recall mammography and psychological distress. Eur J Cancer 2013; 49: 805-11.

12. Hofvind S, Geller B, Vacek PM et al. Using the European guidelines to evaluate the Norwegian Breast Cancer Screening Program. Eur J Epidemiol 2007; 22: 447-55.

13. Kalager M, Zelen M, Langmark F et al. Effect of screening mammography on breast-cancer mortality in Norway. N Engl J Med 2010; 363: 1203-10.

14. Olsen AH, Lynge E, Njor SH et al. Breast cancer mortality in Norway after the introduction of mammography screening. Int J Cancer 2013; 132: 208-14.

15. Lee SJ, Boscardin WJ, Stijacic-Cenzer I et al. Time lag to benefit after screening for breast and colorectal cancer: meta-analysis of survival data from the United States, Sweden, United Kingdom, and Denmark. BMJ 2013; 346: e8441.

16. Roth-Hoff S, Klepp O, Hofvind S. Asymptomatic breast cancer in non-participants of the national screening-program in Norway: a confounding factor in the evaluation of the program? J Med Screen 2013; e-publisert 6.2.2013

17. Falk RS, Hofvind S, Skaane P et al. Overdiagnosis among women attending a population-based mammography screening program. Int J Cancer 2013; e-publisert 25.1.2013

18. Kalager M, Adami HO, Bretthauer M et al. Overdiagnosis of invasive breast cancer due to mammography screening: results from the Norwegian screening program. Ann Intern Med 2012; 156: 491-9.

19. Zahl PH, Mæhlen J. Overdiagnostikk av brystkreft etter 14 år med mammografiscreening. Tidsskr Nor Legeforen 2012; 132: 414-7.

20. Zahl PH, Maehlen J. Overdiagnostisering ved mammografiscreening. Tidsskr Nor Lægeforen 2004; 124: 2238-9

21. Haldorsen T, Tretli S, Ursin G. Overdiagnosis of invasive breast cancer due to mammography screening. Ann Intern Med 2012: 157: 220.

22. Tretli S, Ursin G. Overdiagnostikk ved mammografiscreening. Tidsskr Nor Legeforen 2012; 132 1206

23. Hofvind S, Thoresen S, Tretli S. The cumulative risk of a false-positive recall in the Norwegian Breast Cancer Screening Program. Cancer 2004; 101: $1501-7$

Mottatt 10.8. 2012, første revisjon innsendt 13.11. 2012, godkjent 20.2. 2013. Medisinsk redaktør Siri Lunde.

Engelsk oversettelse på www.tidsskriftet.no

Publisert først på nett. 